\title{
Gender Education in Disruption Era (Study of Virtual Ethnography)
}

\author{
Sudirman $^{1}$, Rosramadhana ${ }^{2}$, Ayu Febryani ${ }^{2}$ \\ ${ }^{1}$ Department of Community Education, Faculty of Science Education, Universitas Negeri Medan, Medan, \\ Indonesia \\ ${ }^{2}$ Department of Anthropological Education, Faculty of Social Sciences, Universitas Negeri Medan, Medan, \\ Indonesia \\ Rosramadhana@unimed.ac.id
}

\begin{abstract}
Education is an academic level without being restricted to gender. Men and women are basically entitled to education. Education for men and women should get the same treatment. Education will continue to experience a complicated phase but will give birth to an established generation in technology. But the challenge of facing the speed of technology will change the way humans work in obtaining education. Education for men and women in the disrupted era has different challenges, but addressing the problems that arise today women will have an impact if the preparation for the era of disruption is not protected by the government. Avoiding participation in the practice of cyber bullying and cybercrime is another form of protection in understanding and responding to this era wisely and wisely. The virtual ethnographic approach is the cornerstone of the strategy to see the development of education for men and women with a model of technology-friendly education to answer the challenges of education in the era of disruption.
\end{abstract}

Keywords

education, gender,

disruptionera, virtual

ethnography

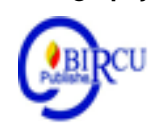

\section{Introduction}

The upheaval in the trajectory of the history of women and men is assumed in the class differences between the superior and inferior groups. Women and man will always be interpreted from various tribal understandings, social class and religion. The dominance of men in various aspects makes women lose opportunities. Women's success is measured by its ability to organize the household as an embodiment of patriarchal culture. Understanding of the nature of women is often used as a shield on the basis of religion and tradition in the context of traditional thinking so that women become marginalized.

Women become a special study because of the polemics surrounding the problems faced by women from various social, economic, legal and political aspects. The movement of women who have been initiated since the beginning did not really bring change to the lives of women. Women are often the subject of exploitation because they are still seen as assets of commercialization of certain parties by arguing to defend women's dignity, but in reality women are only used as an arena for mere symbolic violence which leads to injustice to women.

The practice of oppression of women still occurs in the community, where women are not given the right to gain freedom to explore themselves to develop creativity because of the lack of human awareness to understand women. Restraints on women are based on unequal ideologies because basically it is a strategy to inhibit the progression of women wrapped in the framework of the notion that religion and adat are considered by women to achieve a 
desire that makes women can be used as a pioneer in the development of world mindset third. The movement of women pioneered by feminists encouraged women to rise up and move forward.

Feminism in Indonesia experiences pros and cons, not a few people who consider that the feminist movement is not suitable in Indonesia which has patriarchal eastern culture and strong religious fanaticism. They consider feminism to be doctrine the mindset of Indonesian women, which in turn makes them forget about their duties as women. Although in the beginning the feminism movement in Indonesia was quite a lot that did not support because patriarchal culture was quite embedded in Indonesian society, but did not discourage women from continuing to demand gender equality and defend women from oppression, this situation was seen by women showing their existence. The existence of women who are getting stronger in the current era is accompanied by technological advances that are on par with men. The involvement of women in the public sphere in reaching an era of disruption that is increasingly felt in the new era of industrial revolution 4.0 is addressed by some cyberfeminists by trying to enter into information and communication systems that involve women as actors. But competition in the disruption era shows that women and men are also able to collaborate in various aspects, for example with technology-friendly education. Women and men can use technology by opening equal opportunities, including in terms of helping generic family income.

Education is an academic level without being restricted to gender. Men and women are basically entitled to education. Education for men and women should get the same treatment. Education will continue to experience a complicated phase but will give birth to an established generation in technology. But the challenge of facing the speed of technology will change the way humans work in obtaining education. Education for men and women in the disrupted era has different challenges, but addressing the problems that arise today women will have an impact if the preparation for the era of disruption is not protected by the government. in accordance with the description of the Education Council of the Ministry of Higher Education's Higher Education Council, higher education needs to be aware of the challenges faced in education development, including by providing quality education services to increase the number of people who complete basic education to higher education. This is intended so that the quality of human resources owned by Indonesia can be increased and will be expected to increase productivity and economic competitiveness.

Technological progress will not be able to be blown away, but its utilization strategy in the era of disruption is now used as a trigger for success. Schmitt (2015), R. Morrar, et al (2000) confirmed reasons why Industry 4.0 is important and is seen to be revolutionary in the era of information technology and open market operations. First, Industry 4.0 mitigates the burden of current challenges for manufactures in order to make the companies more flexible and responsive to business trends. Second, Industry 4.0 enables the transformation of modern economies to become more innovative and hence increase productivity. Third, it highlights the role of consumer as a co-producer and puts them in the centre of all activities. The customization of products is the most important activity in the product value chain, and digitization will facilitate crowdsourcing, which in turn will lead to a faster design process. Finally, it will enable sustainableprosperity through the use of modern technologies to find solutions to the challenges.

Online-based education programs are currently very large, for example with online programs and other technology-based non-formal education. The learning process is currently experiencing rapid development, Acceleration of information and access to knowledge 
gained dependency with very fast internet access. This condition actually experiences progress towards a rapid and sustainable way, including in gender education that is quality and based on gender equality. Global achievement in millennial education which is a reincarnation of the old age in the western world is actually a new challenge.

Education is actually a conscious effort in generating competent behaviors and skills for the advancement of education that is standardized and globalized. But education sometimes cannot stand on its own right now. Gender education in the era of disruption is also a form of conscious effort in addressing future opportunities so that gender differences are not an obstacle in utilizing literacy towards the problems of men and women today.

\section{Research Method}

The research approach taken is to use a virtual ethnographic methodology that is investigating the internet and exploring entities (users) when using the internet. Another term in this methodology is known as a neutnographic, 2000) namely special or special forms of ethnographic research adapted to reveal the unique habits of various types of social interactions mediated by computers (the internet) including in the field of marketing. The research informants consisted of users of social media Facebook, Instagram, and start-up users such as Shoopee, Lazada, and Bukalapak. In addition to passing on online interactions, the author also conducts offline meetings or face-to-face meetings with research informants. The virtual ethnographic procedure performed is in accordance with the narrative of Actions, Hines, and Kozinets (Rulli, 2017) that the backing of virtual ethnographic research consists of (1) entering into the cultural arena, (2) obtaining and conducting data analysis from entities, 3) ensuring interpretation of data that matches facts in the field, (4) ensuring research ethics run well, (5) provide an opportunity for the entity or member of the community under study to provide feedback, and (6) must leave the community after conducting research. The data collection is done through observation and interviews both directly and online, and literature studies. Furthermore, data processing is done by knowing background information, types of cyber media, forms of artifacts, social structures of the community and entities, work data related to objects or physical evidence, and beliefs behind cultural artifacts. After that, confirm the results of the research and write a report on the research results.

\section{Result and Discussion}

\subsection{Gender and Education Problems in the Disrupted Era}

Education is a level in achieving national goals, the basic concept of strength in developing education is through the learning process. Strategies in the learning process can be designed to be measurable. Therefore the teacher is a patron in designing interesting models and developments. The social sciences are a series of sciences that move through the dynamics of interesting concepts. Understanding of the concepts in social science stems from basic knowledge, then generalizations (Rosramadhana, 2017).

The disruption era is not a new period, but is considered a new challenge because access to information and communication is fast and globalized. This disruption concept emerged in the development of the 4.0 industrial revolution. In the USA, interest to Industry 4.0 is explained by social goals and changes. Formation of digital society raises demand for further development of innovational technologies, among which robototronics is of the highest interest. At present, the US government has to solve a serious social contradiction 
related to striving for overcoming the unemployment and become the leader in the global competition of industrial innovations. In Industry 4.0, this contradiction is solved with the help of creation of highlyintellectual jobs for servicing robototronics, which will allow overcoming the initial unemployment and satisfying the growing needs for opening the creative potential of American workers. Visible results in Industry 4.0 are to be achieved by 2022 (S. Lobova, 2019). In line with the development of an all-digital era and a global technological struggle, both men and women must be able to compete and be alert to the current that cannot be stopped now and in the future. Gender education for women and men in the current era of disruption is based on maturity in utilizing technology.

Gender education in the current era of disruption is focused more on opportunities for the use of appropriate technology. Women and men can use technology as a field to get information, applications and even develop digital-based knowledge. The thing that is related to technological developments today is the problem that arises. The readiness of women and men in terms of education currently seems to be still relatively inequality especially in the challenges of the current disruption era. According to Suarmini, et al (2018), Although the industrial revolution 4.0 has promising prospects, there are a number of challenges faced by female professional workers to work in the industrial world. The 2015 UNESCO study shows the low level of participation of female workers in industry. This is due to the perception that the work environment in the industry is the domain of men's work, which involves physical work and is not attractive to female workers. In addition, there are still not many female graduates who pursue industry careers. Most women workers choose to work in administration and management that are not directly related to their field of expertise.

Other problems among women in education usually occur after women experience a period where women are faced between careers and households. With this disruption era, women are not only seen as second class human beings in the patriarchal cultural system. Women can take part without being constrained by the constraints of socio-cultural constructions that have been quite shackled. However, women have a strategic role in providing the best education for children. If women take part in the public sphere, surely they must balance their roles which are more important in the domestic sphere, namely as generation educators. In relation to this, women must open themselves to this era of industrial revolution 4.0. The progress of the times and the rapid development of technology, requires women to be able to use the capabilities of Information and Communication Technology (ICT) optimally. Moreover, to measure the extent to which a country's development is gender based, it can be measured by the optimal treatment of gender equality in the country.

Women as generation educators must be able to master the development of the times to be able to educate children in accordance with their times. Through mastery of ICT, the development and dissemination of information can be found easily and quickly. Information received can encourage economic growth which can later support the improvement of quality of life. However, women also have to be able to provide various foundations in behaving so that they can form a generation with character. Platforms such as strengthening nationalism (love of the homeland), understanding the values and norms of Indonesian culture are important things to be able to be mastered by women so that later they can transfer that knowledge to children. According to Lestari (2011), equality of access and mastery of the technology of information and communication for women and men has become a global concern. Gender issues and information and communication technology have been included since the 1995 Beijing declaration which is the result of the fourth conference on women. Likewise, the Sustainable Development Goals (SDGs) program on gender equality 
emphasizes increasing the use of information and communication technology for women's empowerment Suarmini, et al (2018).

Gender education in the era of disruption certainly does not only discuss the efforts of women to achieve gender justice. More than this, in this era men and women have the same contribution in determining their lives. Based on International Telecommunication Union (ITU) data, shows that the percentage of ICT users for women is still lower than that of men. The inhibiting factors for women in developing countries to master ICT are low education, literacy, language, time, costs, social and cultural norms.[6]. The socio-cultural construction that views women as only sufficient in the domestic sphere, inhibits the movement of women to actively participate in development. Therefore, if all this time the domestic realm is dominated by women in managing it, then in this era men are also required to be able to master the domestic sphere. Likewise women must also be able to contribute to the public sphere. Because freedom and equality must not be limited socially so that every human being has the potential to develop himself as widely as possible

So far, the socio-cultural constructions supported by religious orders that the task of earning a living are men and caring for children are women, making them seem to limit their social movements. In some companies, for example, women tend not to be prioritized in recruiting employees due to their nature of pregnancy, childbirth, and breastfeeding. This condition is felt to hamper the stability of the company because its employees must take time off from work. However, in this era of disruption, both men and women do not need to feel dependent on hiring employees in various companies. Through the use of technology, both men and women can open independent businesses online through online shop sales of various available applications. Marx (J. B. Foster, 2018) said that much of this change was due to factory legislation, the ten-hour day, rising wages, and the now official bourgeois ideology of the male breadwinner and the female housewife. The last served to strictly define gender roles in the newly emerging era of monopoly capitalism, in which relative surplus value, as opposed to absolute surplus value, was dominant.

In addition, the social reality that the use of technology has begun to be implemented by women can be seen from the presence of a community of herbal medicine sellers carrying in North Sumatra. The sellers of herbal medicine carry out sales innovations that not only sell their watches directly, but are also trained to be able to open an online business. Entrepreneurship development for herbal medicine sellers through social media has become important in this era because the range of selling herbs directly is certainly limited. Therefore, one of the women's organizations called PESADA (women's strengthening organization), chaired by Dina Lumbantobing, trained 15 people selling herbal medicines in Medan through the Medan Women's Urban Foundation. The workshop was also carried out to provide awareness to the seller of herbal medicine about the equality and ability to earn income. In addition, training was also held to introduce social media to herbal sellers to run entrepreneurship more widely.

The herbal sellers are not so familiar with social media. Among others, they feel that social media is not important for their business. So that this reinforcement needs to be transmitted to the children of herbalist sellers to provide an insight into the mastery of the use of social media to their mothers. After knowing the benefits and uses, herbal medicine sellers are introduced to be able to market their products, especially determining what packaging is attractive so that their products are worthy of being sold on social media.

In some start-up applications you can find various forms of existing herbal products. Not only that, the women have also opened an online shop by selling various products 
including hijab, clothing, shoes, bags, and other household supplies. Even though women do not have capital in kind, but with their position as resellers, they can market the product as if the product is available in their online shop. In addition, the latest innovation has also been launched by Sido Appears by creating soft capsules made from the development of Sido Muncul's liquid herbal products. Previously this product was wrapped in sachet packaging. This innovation is increasingly giving direction to changes that support the development of the industrial sector. Sido Muncul as a producer of traditional medicine is able to inspire, innovate, and open up opportunities for export markets whose hopes can be emulated by other herbal sellers..

The 2016 BPS data shows that gender equality is getting better. The emancipation of women produces encouraging results. Women are increasingly active in various aspects of life. The following is a data table that shows the role of women in 2015.

Table 1. The Role of Women in 2015

\begin{tabular}{|c|c|c|}
\hline No & Activities & $\begin{array}{c}\text { Percent } \\
\text { age }\end{array}$ \\
\hline 1 & Women as professionals, leadership, and technicians & $46,03 \%$ \\
\hline 2 & Contributions to women's income in the economy & $36,03 \%$ \\
\hline 3 & Women in Parliament & $17,32 \%$ \\
\hline
\end{tabular}

Source : bps.go.id (Badan Pusat Statistik, 2017)

Table 2. The Behavior of Indonesian Internet Users on Social Media for activities

\begin{tabular}{|c|l|r|c|}
\hline No & \multicolumn{1}{|c|}{ Activities } & Percentage & Number of Population \\
\hline 1 & sharing information & $97,5 \%$ & $129,3 \mathrm{~m}$ \\
\hline 2 & Trade & $94,6 \%$ & $125,5 \mathrm{~m}$ \\
\hline 3 & Dissemination of Government Policy & $90,4 \%$ & $119,9 \mathrm{~m}$ \\
\hline 4 & Calling the Religion & $81,9 \%$ & $101,6 \mathrm{~m}$ \\
\hline 5 & Politics & $75,6 \%$ & $100,3 \mathrm{~m}$ \\
\hline
\end{tabular}

Source: Results of the 2016 Survey- Polling- DAAI TV

Based on these data the Human Development Index for men and women has increased. The Human Development Index (Men) has increased from 2010-2015, from $70.94 \%$ to $73.58 \%$ and women experienced an increase from $63.43 \%$ to $66.98 \%$. This Gender Development Index shows that the closer to 100 , the smaller the inequality that occurs between women and men. This disruption era has increasingly shown that widespread participation gives men and women the freedom to contribute. This is reinforced by the high number of trading activities $(94.6 \%)$ on the behavior of internet users on social media for activities.

Social innovations are known as new practices used to tackle social challenges; they have a positive influence on individuals, society, and organizations (Hahn \& Andor, 2013). Social innovations have also been defined as new models, services, and products that simultaneously meet social needs (Marolt et al., 2015). They can be expressed by one or a combination of the following: law, regulation, behaviour, service, business model, perception, organization, or technology (Abott, 2014).

Innovations in the use of technology have also been carried out by farmers. Farmers can sell their produce online through available marketplaces such as Agromaret, TaniHub, Petani, Pantau Harga, dan LimaKilo. Through the various available marketplaces, farmers can break 
the long chain of distribution so that the benefits felt by farmers can be more felt and communication with consumers can be formed directly. If so far the mastery of technology among farmers is considered to be a problem, but now with the various socialization of ICT education both held by the government and non-government, farmers are starting to try to be able to expand their access. This not only requires the intelligence of male farmers, women farmers must also be able to master the ability to use ICT. In the end, farmers can set themselves apart, so that later there will be no more farmers who are in debt with loan sharks. This is in accordance with the description of the Education Council of the Ministry of Higher Education's Higher Education Council that independence actually reflects the attitude of a person or a nation regarding himself, his community, and his enthusiasm in facing challenges. Because it concerns attitude, independence is basically a cultural problem in the broadest sense. The attitude of independence must be reflected in every aspect of life, both legal, economic, political, socio-cultural, and defense security.

\subsection{Technology Friendly Education}

Technology-friendly education is a concept related to the ability of individuals to understand the use of technology wisely. A form of education that can provide convenience as well as the ability to control all information that is spread wisely. Technology is certainly intended for all education. Educational and family institutions are a major milestone in channeling understanding of technology-friendly education. Don't let individuals misuse technology.

Cyber bullying is one example that when individuals, both men and women are not able to use technology wisely, it will experience cyber abuse. Definitively, cyber bullying or online social cruetly Kowalsk, 2008) or electronic bullying (S. Shariff, 2011) or social terror through technology is intentional, repetitive behavior, or negative habits by using information and communication technology, such as e-mail, instant messaging, and personal sites by individuals and groups with the intention of hurting others. Indonesia is currently entering this cyber bullying era. Especially with the various political conditions in Indonesia, making netizens freely abuse anyone with various forms of insults, intimidation, the spread of hoaxes, speeches of hatred, both aimed specifically at the victims and with public knowledge.

In addition, individuals must also understand the concept of cybercrime in order to avoid online crime which is now increasingly prevalent in the mass media. Various cases must at least be understood such as illegitimate eavesdropping, bank fraud, money laundering, network use of other parties, pornography, copyright infringement, virtual terrorism, online gambling, credit card forgery, situ plagiarism, data destruction, virus spread, and damage to computer systems (R. Nasrullah, 2016). Therefore, cybercrime must also be anticipated by mass media users. This disruption era, everyone can be a disseminator of information broadcast on their respective social media. Even mass media such as television, radio, and print media also tend to use various images or amateur recordings from information disseminators in the mass media. Therefore, caution is important in using online media.

Global competition in this era also requires everyone to be able to create and innovate in creating their cultural products. The concept of innovation in this era of disruption has actually been initiated by Bower and Christensen 1995, namely technological innovation. Digitalization in several aspects becomes a benchmark in seeing the progress of development in a region. Even the term "survival of the fastest" is quite a trend in this disruption era. That anyone who is not swift and capable in responding to the development of the times, will tend 
to experience lagging. Gardiner (D. Mayling, 2017) revealed that technology encourages various changes, not only in technology itself but also in human life, the way humans relate, the way we organize, therefore developing creativity and innovation is important to improve.

According to the population census that was first implemented by Indonesia since independence in 1961, it was noted that of the 31.3 million men aged 10 years and over, 53 percent had never attended school. As for women, the term is much higher at 76 percent. As is true in many other countries, the higher the level of education, the greater the difference in women's participation compared to men. Therefore, at this time the young and old generation, men and women must have a stake in building Indonesia. Being a conscious generation of technology-friendly education is a way of addressing this disruption era wisely and wisely, so as to create advanced human resources in Indonesia.

\section{Conclusions}

Gender education in the era of disruption must be addressed intelligently and wisely. The era of digitalization provides great potential for each individual to contribute to every domain. In addition, both men and women must understand the concept of gender equality so that they can fill this era with creativity and innovation. However, individuals must be able to filter so they can avoid the practice of bullying both as perpetrators and victims. In addition, intelligence and precision are needed in using social media so that it can avoid the practice of cyber crime that is increasingly rampant.

\section{Acknowledgements}

Acknowledgments are conveyed Universitas Negeri Medan for giving the writer an opportunity to conduct research and thank you for the motivation of the faculty leaders.

\section{References}

Badan Pusat Statistik. (2017). "Kesetaraan Gender," bps.go.id

C. Hine. (2000). Virtual Ethnoraphy. London: SAGE Publications, Ltd

Rulli Nasrullah. (2017). Etnografi Virtual - Riset Komunikasi, Budaya, dan Sosioteknologi di Internet. Bandung: Simbiosa Rekatama Media

C. M. C. Bower, Joseph L., "Disruptive Technologies: Catching The Wave," Harvard Bus. Rev. 73, vol. 1, pp. 43-53.

D. Mayling Oey Gardiner. (2017). Era Disrupsi (Peluang dan Tantangan Pendidikan Tinggi Indonesia. Jakarta: Akademi Ilmu Pengetahuan Indonesia.

D. S. Y. A. Ni Wayan Suarmini, Siti Zahrok, "PELUANG DAN TANTANGAN PERAN PEREMPUAN DI ERA REVOLUSI INDUSTRI 4.0," Pros. SEMATEKSOS 3

"Strategi Pembang. Nas. Menghadapi Revolusi Ind. 4.0," pp. 48-53.

J. B. Foster and B. Clark. (2018). "Women, Nature , and Capital in the Industrial Revolution," no. June

R. M. Kowalski. (2008). Cyber Bullying: Bullying in The Digital Age. Malden, MA: Blackwell Publishing.

R. Morrar. (2017). H. Arman, S. Mousa, and K. Schwab, "The Fourth Industrial Revolution ( Industry 4 . 0 ): A Social Innovation Perspective,” vol. 7, no. 11, pp. 12-21.

R. Nasrullah. (2016). Media Sosial- Perspektif Komunikasi, Budaya, dan Sosioteknologi. 
Bandung: Simbiosa Rekatama Media.

Rosramadhana,. (2017). "Desain Pendidikan Ilmu-Ilmu Sosial Berwawasan Kebangsaan," Pros. Semin. Nas. Tah. Fak. Ilmu Sos. Univ. Negeri Medan Tahun 2017, vol. 1, no. 1, pp. $147-150$.

S. Lobova. (2019). "Successful Experience of Formation of Industry 4 . 0 in Various

Countries Successful Experience of Formation of Industry 4 . 0 in Various Countries," no. July 2018

S. Shariff. (2011). Cyber Bullying. London and New York: Routledge. 